\title{
Periodontal disease in Rice-cultivating Yayoi People of Ancient Japan
}

Takashi Uekubo (Division of Community Oral Health Science, Kyushu Dental College)

The purpose of the present study was to clarified the incidence of periodontal disease in the ricecultivating Yayoi people of ancient Japan. The cementoenamel junction-alveolar crest (CEJ-AC) distance was examined in 295 ancient human bodies excavated from 52 archaeological sites considered to belong to the Yayoi period in Japan (ca. 500 B.C. - 300 A.D.). The severity of periodontal disease was mild in the adolescent group, whereas it was aggravated in the elderly group, who also showed marked alveolar bone loss. Periodontal disease tendency was most remarkably observed in the first molar. Periodontal disease tended become aggravated with aging in Yayoi people. We concluded that there was a higher incidence of severe periodontal disease in the present study population as compared to reports of other ancient human peoples.

\section{8 月例会講演抄録}

\section{1. 低カルシゥム飼料飼育ラットの脛骨骨幹端の機械的特性の变化におけるブドウ種子エキスの影響}

三井 潤 (九歯大·口腔機能発達学)

本研究は, 低カルシゥム飼料の摂取により骨虚弱状態を惹起したラット脛骨骨幹端に対してフラボノイド類である ブドウ種子エキス grape seed proanthocyanidins extract (GSPE) と高カルシゥム飼料が軟骨内骨化による骨形成 にどのような影響を及ぼすかを peripheral Quantitative Computed Tomography（pQCT）を用いた 3 次元的な 力学的解析を行った。さらに脛骨の破砕試験による侵襲的骨強度測定を行った，その結果, 高カルシゥム飼料之 GSPE の併用食事療法は, 成長期ラット脛骨骨幹端の骨形成における内部構造に影響を与え, 特に骨量·骨質を増大 させることが明らかとなった。

\section{Effects of grape seed proanthocyanidins extract on alteration of mechanical properties of metaphysis tibia bone in rats fed a low-calcium diet}

Jun Mitsui (Division of Pediatric Dentistry, Kyusyu Dental College)

Five-week old male Wistar rats $(\mathrm{n}=40)$ were randomly divided into a control (Co) group, a lowcalcium diet (LC) group, a low-calcium diet-high-calcium diet ( $\mathrm{LCH}$ ) group, and a low-calcium diet . high-calcium diet with supplementary GSPE (LCHG) group. The metaphysis tibia bones were analyzed using three-dimensional pQCT. Trabecular bone density (TrBD), trabecular bone mineral content (TrBMC), cross-sectional moment of inertia to the reference axis y (yCSMI), and stress-strain index to the reference axis $x$ (xSSI) in the LCHG group were significantly higher than those in the LCH group $(\mathrm{p}<0.05 ; \mathrm{p}<0.01 ; \mathrm{p}<0.05 ; \mathrm{p}<0.05$, respectively), while stiffness in the LCHG and LCH groups were significantly higher than that in the LC group $(p<0.01)$. We concluded that a mixture of high-calcium and GSPE in the diet has a more beneficial effect on bone formation for the treatment of metaphysis tibia bone debility in rats than dose a high-calcium diet alone.

\section{0 月例会講演抄録}

\section{1．ラット単離脳弓下器官神経細胞における一過性外向きカリゥム電流とアンギオテンシン II 効果}

小野堅太郎（九歯大·生理学）

喉の渇きに関与する脳弓下器官神経細胞はアンギオテンシン IIにより一過性外向きカリウム電流を抑制するが, よ゙ のような $\mathrm{Kv}$ チャネル分子が関与しているか全く報告されていない。よって，様々な手法を用いてラット単離脳弓下 器官神経細胞における $\mathrm{Kv}$ チャネル分子について検討した. RT-PCR 法によって, 候補となる Kv3.4, 1.4 ならびに 